UDC: $821.14^{\prime} 02: 326$

Немања Вујчић

Универзитет у Београду

Филозофски факултет

nemanja.vujcic@f.bg.ac.rs
Оригиналан научни рад

примљено: 2. април 2013

прихваћено: 1. октобар 2013

\title{
РОПСТВО КАО ПОРОК У БЕСЕДАМА ДИОНА ИЗ ПРУСЕ
}

Сажетак: Дион из Прусе један је од најважнијих грчких беседника и филозофа царског доба. Поред значаја за историју књижевности и културе, Дионове беседе се често користе и као историјски извор, поготову за нека питања друштвене историје. Релативно честе референце на ропство у Дионовим говорима, понегде праћене и негативним моралним судом, побуђују наду да би се овај аутор могао искористити као извор за историју античког ропства у I и II веку н. е. У којој мери је реалност ове институције нашла одраза у Дионовим дискурсима? А ако је ипак реч о личном ставу интелектуалца, да ли овде, најзад, имамо пример античког мислиоца који је доследно и недвосмислено критиковао и одбацивао читав феномен? Површно читање одређених места у Дионовом опусу би могло навести на позитиван одговор на оба питања, али пажљивија анализа показује да очекивани закључак није ни недвосмислен ни једноставан.

Кључне речи: Дион из Прусе, ропство, робови, осуда ропства, друга софистика, Римско царство.

Беседник, филозоф, припадник провинцијске елите и политички изгнаник, Дион из Прусе (или Дион Хрисостом) једна је од занимљивијих и колоритнијих личности грчке историје у доба Римског царства. ${ }^{1}$ Спадајући у водеће личности епохе друге софистике, Дион је био у прилици да пажљиво, из разних углова, сагледа себи савремен свет источних провинција Римског царства. Овај образовани припадник муниципалне аристократије из Прусе у Битинији имао је доста нетипичан животни пут. Био је у прилици да упозна сам врх провинцијске елите, мноштво угледних Римљана, па чак и самог цара Трајана, али је такође искусио

1 Избор из литературе о Диону: Н. von Arnim, Leben und Werke des dio von Prusa, Berlin 1898; Т. BekkerNielsen, Urban Life and Local Politics in Roman Bythinia: The Small World of Dion Chrysostomos, Aarhus 2008, 119-140; G. W. Bowersock, Greek Sophists in the Roman Empire, Oxford 1969, 110-112; ibid., The Literature of the Empire, y: P. E. Easterling, B. M. W. Knox, The Cambridge History of Classical Literature I: Greek Literature, Cambridge 2003, 669-672; A. Lesky, Geschichte der griechischen Literatur, München 19993, 932-933; J. L. Moles, The Career and Conversion of Dio Chrysostom, JHS 98, 1978, 79-100; M. H. Ђурић, Историја хеленске књижевности, Београд 1996, 741. 
изгнанство, нашавши се у немилости код Домицијана, те сиромаштво и елементарну егзистенцијалну неизвесност. ${ }^{2}$ Сачувани Дионов опус је доста велик (78 аутентичних говора) и често је коришћен од стране историчара, историчара књижевности и филозофије. Богатство изворних информација које Дион нуди чини се непрегледним и неисцрпним, а ипак коришћење његових говора као извора често је повезано са великим тешкоћама. Дионов свет је, карактеристично за епоху друге софистике, напола утонуо у грчку класичну старину. Историјске личности као што су Сократ, Диоген или Александар Велики, те митолошке фигуре попут Херакла и Агамемнона, уобичајени су елементи Дионовог излагања. Неретко се читалац његових дискурса готово нађе у недоумици да ли је пред њим аутор из II века н. е. или је то, ипак, неки атински беседник V века ст. е. Поред општег класицистичког и архаизирајућег манира, Дионов начин приповедања, будући дубоко рефлексиван и морализаторски, уз честа ослањања на симболе и метафоре, нимало не олакшава коришћење његових дела као историјског извора. Читалац је ретко кад на чврстом тлу а много чешће у недоумици да ли је појединост о којој чита нешто изведено из Дионовог искуства и историјске стварности, или можда пре прерада неке погодне епизоде из класичне књижевности, или чиста фикција, која писцу служи као канал за поруку коју упућује. Свакако, Дионов опус садржи и знатан број сасвим конкретних говора, осмишљених ради непосредне (углавном политичке) сврхе али они су у мањини а ни сами нису лишени извесних интерпретативних тешкоћа. ${ }^{3}$

О значају институције робовласништва у историји античког света и великој контроверзи коју изазива у модерним дискусијама, не треба посебно говорити. У Дионовим говорима институција ропства се спомиње сразмерно често. Поставља се питање да ли су многобрајна места на којима Дион разматра робове и ропство употребљива као историјски извор за ропство у његово доба (I-II век н. е.) или је сигурније схватити их као одраз ауторових тежњи и схватања. Читаво питање са свим бројним импликацијама овде нећу разматрати, уместо тога покушаћу да анализирам Дионов вредносни суд о ропству. ${ }^{4}$ Да ли Дион осуђује ропство и у ком смислу? Ако је одговор потврдан, какве су последице такве осуде и остаје ли она у чисто теоријским оквирима?

Ропство је, наравно, и даље жив предмет интересовања и у модерном свету и студије посвећене овој институцији су многобројне. Драматична улога коју су трговина робљем и експлоатација робовског рада играле у историји ране модерне Европе и Сједињених Америчких Држава чини да ропство опстаје као стална компонента савремене историјске свести, далеко превазилазећи оквире једне академске дискусије. То интересовање за нововековни феномен ропства прелива се и на студије античког ропства, па и на разматрање места које оно има у Дионовом опусу. Студије ропства у новијој историји су, у целини, деловале подстицајно на

\footnotetext{
2 Dio Chr. XIII 1; Philostr. VS 486, 19-488, 34; Eun. VS 454.

3 Dio Chr. XXXI-L.

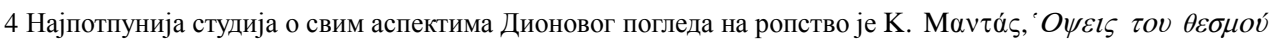

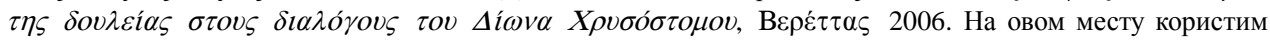
прилику да захвалим аутору, Константиносу Мантасу, на томе што ми је посудио верзију текста на енглеском језику.
} 
проучавање античког ропства, мада постоје и сфере где је тај утицај био мање благотворан. Пре свега, постоји негативна тенденција да се античко ропство посматра просто као ранија верзија нововековног феномена, упркос значајним разликама. ${ }^{5}$ Једна од последица овог става је и a priori очекивање да и антички феномен садржи све оне елементе који карактеришу нововековни: чврста и нераскидива веза између прекоморске експанзије и увећања броја робова, велико место робова у привреди, нарочито земљорадњи, расна сегрегација, раширена интелектуална дебата о ропству и свим његовим аспектима, постојање организованих покрета за укидање ропства (аболиционисти итд.). ${ }^{6}$

Да се задржимо само на последња два аспекта, пошто су они од непосредног значаја за разматрање Дионове карактеризације и евентуалне осуде ропства, антички мислиоци су утрошили релативно мало енергије на разматрање ове институције, док апсолутно никакав покрет чији би циљ било ослобађање робова није постојао. Антички писци, филозофи пре свега, спорадично разматрају институцију ропства, но тешко да она спада у велике теме филозофске теорије. Карактер античког разматрања ропства је упадљиво недраматичан: оно се углавном просто подразумева, понекад аргументује и брани, ретко критички анализира. Потрага за античким аболиционизмом или бар за једним јединим заговорником укидања ропства у антици није дала резултате. ${ }^{7}$

Постоје, међутим, разлози да се ставови античких аутора I-II века н. е., и грчких и римских, сматрају изузетним у односу на њихове претходнике, што је можда последица измењених околности и саме друштвене улоге ропства. ${ }^{8}$ Код једног броја аутора налазимо оштрије разматрање негативних аспеката ове институције. Нарочито пада у очи појава мишљења, понегде израженог снажним речима, да су и робови људска бића и да их као такве треба и посматрати. ${ }^{9} \mathrm{C}$ друге страна, аргументација остаје у оквирима и категоријама наслеђених из ранијих векова, поготову стоичке доктрине о истинској тј. духовној слободи и ропству. Роб је онај човек који нема самоконтролу, који робује својим страстима и туђим утицајима (иако је можда правно слободан), слободан је онај човек који влада собом и држи

5 P. Temin, The Labor Market of the Early Roman Empire, The Journal of Interdisciplinary History 34-4, 2004, 522-523.

6 У најсвежијем општем прегледу N. McKeown, Greek and Roman Slavery, y: G. Heuman, T. Burnard (edd.), The Routledge History of Slavery, New York 2011, 19-34, античко ропство се посматра као уводно поглавље у историју модерног ропства. Иако ова публикација види себе као „прекретницу која нуди преглед главних тема у вези са историјом ропства од античке Грчке до данашњице“ (стр. ii), она заправо се бави само једним бројем тема из историје нововековног ропства и трговине робовима на Атлантику у XVIII и XIX веку. Целина о грчко-римском ропству (друга античка друштва се не спомињу) унета је у духу старе традиције која класично ропство схвата као претходника модерног.

7 G. E. M. de Ste. Croix, The Class Struggle in the Ancient Greek World, Ithaca 1998, 418-441; ibid., Slavery and Other Forms of Unfree Labor, y: L. Archer, Slavery and Other Forms of Unfree Labor, London 1988, 2830.

8 W. L. Westermann, The Slave Systems of Greek and Roman Antiquity, Philadelphia 1955, 126-127.

9 И роб је човек: Sen. Ep.V 47. Брутално кажњавање робове је за осуду: Sen. Ira III 24, 32, 40. Напуштање старих и болесних робова је за осуду, убиство роба је злочин: Suet. Cl. 25; Cass. Dio LX 29. Разумевање за робове који су покушали да убију лошег господара: Pl. Ep. III 14. Cf. Ulp. Dig. XLVIII 18, 1. 
своје страсти под контролом (макар био роб по слову закона). Ипак, сама институција ропства се нити напада нити одбацује. Покушаја њеног укидања или реформе једноставно нема. Где се, онда, у свему томе налази Дион?

Ропство се разматра на више места у Дионовом опусу. Истичу се VII, X, те XIV и XV беседа, мада значајних мисли има и другде (на пр. Or. XV 9, XXXI 109 итд.). У VII или Еубејској беседи Дион описује један догађај из времена свог изгнанства а затим га користи као полазиште (у другом делу беседе) за моралну критику извесних друштвних слабости и порока; беседа је од потенцијално огромног значаја за друштвену историју али њено коришћење као историјског извора је скопчано са великим тешкоћама, почев већ од питања аутентичности читаве епизоде. ${ }^{10}$ Диоген или $O$ слугама је Х беседа, изложена у форми фиктивног дијалога између филозофа Диогена и старца кога је напустио једини роб. Беседе XIV и XV су директно посвећене питању ропства. Обе имају форму дијалога. У првој беседи Дион (филозоф) и неименовани саговорник (лаик) разматрају појмове ропства и слободе. Друга је изнета кроз разговор између слободног човека и роба смештен у Атини.

У Еубејској беседи ропство није основна тема. ${ }^{11}$ Централно место заузима контраст између порочног градског начина живота, оличеног у неименованом еубејском граду, и пасторалне идиле еубејских ловаца. Они и њихове породице живе скромно али срећно, од властитог рада у настамбама које су сами саградили. Склад, ментални и физички, потпун је и овој изолованој групи контакт са спољним светом није неопходан и настаје тек као последица неизазване интрузије. Еубејски ловци немају много имовине, новца немају уопште, најзад - немају ни робове. ${ }^{12}$ Искварена урбана заједница је њихова супротност. Град је место великих страсти, очекивања и неконтролисаних амбиција. Али тај град није и срећно место а немар његових становника и презир према физичком граду чини да он и економски пропада: пространо пољопривредно земљиште око града је запуштено, као и јавне површине у самом граду. ${ }^{13}$ Упркос томе, грађани, за разлику од ловаца, показују велико интересовање за материјалну добит, а бар део њих држи и робове.

Други део беседе садржи одређеније ставове о проблему ропства. Разматрајући пороке градског живота и могућа зла на које урбано сиромаштво приморава људе, Дион међу делатности срамне за грађане убраја и хватање одбеглих робова, односно објаву награда за њихово хватање. ${ }^{14}$ Мало даље, беседник осуђује трговину женама и децом отетим у рату и сексуално искоришћавање робиња, без обзира да ли су по рођењу Хелени или варвари. ${ }^{15}$ Али сваки генерални закључак, изведен из ових редова, не издржава анализу ширег контекста. Да, хватање одбеглих

10 За ово питање: Н. Вујчић, Еубејска беседа Диона из Прусе као историјски извор, у: К. МарицкиГађански (ур.), Античка култура, европско и српско наслеђе. Зборник радова, Београд 2010, 93-112.

11 Први део беседе (гл. 2-80) преведела је на српски језик Челица Милановић у: М. Флашар (ур.), Повести из грчке књижевности, Београд 1986, 349-369.

12 Dio Chr. VII 10-20, 42-47.

13 Dio Chr. VII 34-39.

14 Dio Chr. VII 123-124.

15 Dio Chr. VII 133. 
робова и сродне делатности Дион сматра срамним, али такав став је преовладавао у античком свету. Парадоксално, трговина робљем је сматрана нечасним занимањем, трговци робљем морално сумњивим људима, иако су богати људи античког Медитерана без скрупула користили њихове услуге, куповали и поседовали робове. ${ }^{16}$ Ни Дион не иде даље од начелне осуде: објавити награду за хватање одбеглог роба је нечасан поступак - стога нећемо дозволити нашим суграђанима, ма како били сиромашни, да се баве тиме. Тај посао ћемо препустити странцима, по могућству нехеленима. Трговина женама и децом је много одређеније осуђена али, поново, један поглед на контекст квари закључак коме се модеран читалац нада. Таква трговина је за осуду уколико се жртве купују за потребе јавних кућа јер се тиме подстиче опште зло какво је проституција. ${ }^{17}$ Беседник нигде не наводи да је ропство само по себи лоше или да је трговина робовима за осуду као таква. Сексуално искоришњавање робова, у јавним кућама и домаћинствима је лоше, али не толико само по себи, колико зато што води нечему другом:

Дакле, потребно је да се подсетимо на то да је међу нама постала тако видљива ова срамота почињена над неграђанима, тако потпуно безобзирна и нескривена, да отвара пут за нападе, у тајности и помрачини, на невиност угледних жена и младића, пошто се таквим неделима приступа са лакоћом тамо где је пристојност отворено одбачена...

Другим речима, човек који се препушта страстима у додиру с робовима временом ће изгубити контролу над собом, препустити се пороцима и постати претња за грађане, за „невиност угледних жена и младића“. Искоришћавање робова може да буде један од узрока великог друштвеног зла. Дион сматра да је искоришћавање робова порочно и само по себи - то се може наслутити у тексту али је ипак од мале важности у односу на веће друштвено зло, које га превасходно интересује.

У X беседи, Дион излаже приповест смештену у фиктивно класично окружење: на путу који води из Коринта, Диоген среће ужурбаног, неименованог старца. На питање куда иде, старац објашњава филозофу да је путовао у Делфе да постави питање пророчишту. Међутим, при проласку кроз Беотију његов једини роб је побегао и старац га сада тражи, надајући се да је можда у Коринту. ${ }^{19}$ Диогеново чуђење над бесмислом његовог подухвата (потера за одбеглим робом) служи као покретач за дужу расправу. Између осталог, Диоген констатује да се бекство није десило без разлога: или је овај био лош роб, или је господар био лош према њему, или су обојица били лоши један за другог. У сваком случају, њихова заједница је лоше функционисала и не треба је обнављати:

16 M. Finley, Aspects of Antiquity: Discoveries and Controversies, Harmondsworth 1977, 154.

17 Dio Chr. VII 133-138.

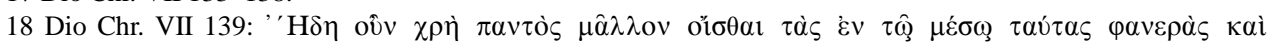

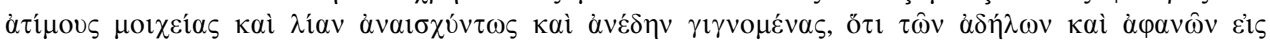

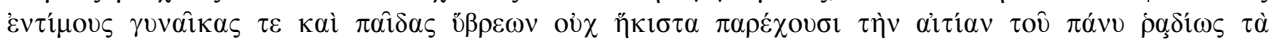

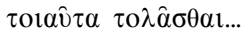

19 Dio Chr. X 1-2. 
Напослетку он је, рече, мислећи да си ти лош од тебе побегао, да му ти не би наудио. А ти њега, за кога тврдиш да је лош, тражиш! Зар није очигледно да лоши људи наносе штету онима који их поседују или их користе, било да је реч о Фрижанима или Атињанима, било да су у питању слободни или робови? ${ }^{20}$

Јасно је да на овом месту (и другде у истом тексту) Дион гледа на одбеглог роба као на личност. Роб је донео одлуку да побегне, одлуку на коју по грчким схватањима и законима није имао право, али за коју Дион, кроз наводне Диогенове речи, има разумевања. Готово као да тврди да роб има право да напусти лошег господара. Значај дистинкције између слободних и робова је релативизован, баш као и разлика између Хелена и варвара (Атињана и Фрижана). Да ли бар ови ставови воде у осуду ропства као таквог, у одбацивање читаве институције? Очекивања у том правцу поново остају неиспуњена. Дион у X беседи излаже одређене ставове киничке школе, односну своју интерпретацију тих ставова. Суштина је у одбацивању артифицијалног света који је створио човек и повратак природном стању. Између осталог, негира се значај и институција својине, тиме и својине над робом. Али та негација не води ни у какав друштвени активизам, позив на укидање институције и борбу против ње. Да ли ће одустати од роба или га даље прогонити је, у крајњој линији, господарева лична ствар. Дионов Диоген може да исмева и приказује апсурдним његов избор али га не осуђује, чак је и етичко разматрање поступка изостало. Диоген против потере за робом износи чисто утилитарне аргументе: господар треба да има у виду да се ослободио муке, напора, трошка. Одбеглог роба не мора више да храни, одева, негује у случају болести, док су вредноћа и употребљивост овога ионако под знаком питања. ${ }^{21}$ Кинички идеал појединца који живи само од онога што му природа даје и који не зависи од туђе помоћи, овде је приказан из занимљивог угла.

Најзад, Дионов Диоген се олако служи метафорама које не одају дубоко поштовање за роба и његову личност, упркос споменутом разумевању. „И нико рђаво псето не прогони ако га таквим сматра, а неки такво избаце напоље ако покуша да се врати“, саопштава Диоген. ${ }^{22}$ И даље: „Причају да су Актеона раскомадали бескорисни пси и то махнити. Али ко може рећи колико је обичних људи и краљева и читавих градова уништено од стране бескорисних људи, међу њима и кућних робова...“ “23 Духовите аналогије ту не престају, на питање старца шта ће да ради и како ће да живи без ичије помоћи, Диоген пореди одбеглог роба са лошом ципелом: „А шта ћеш да радиш ако немаш других ципела сем оних које ти муче и секу

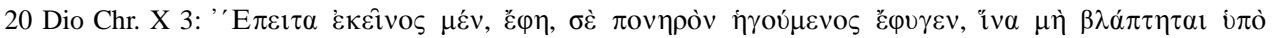

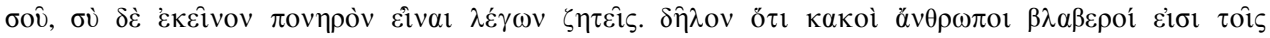

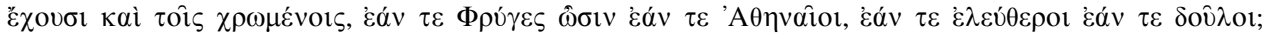
21 Dio Chr. X 12-13.

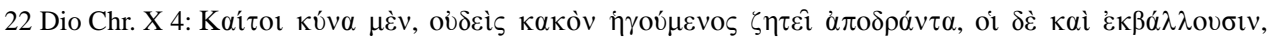
$\dot{\varepsilon} \dot{\alpha}^{2} \dot{\varepsilon} \pi \alpha v \dot{\varepsilon} \lambda \theta \eta \emptyset$.

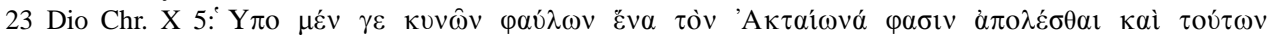

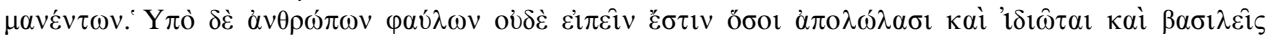

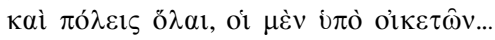


стопало? Зар их нећеш одмах свући и наставити босоног? А ако се оне саме од себе расплету, да ли ћеш их поново везати и пригушити стопало?“24 За Диона, робови су људи али његов став о њима ипак не излази из круга уобичајених схватања њему савремене грчко-римске елите.

„Људи желе да буду слободни више од свега на свету и говоре да је слобода највеће добро а да је ропство најсрамотнија и најнесрећнија позиција. Али шта је заправо то слобода или шта је то ропство, они не знају.“25 Овим речима Дион отвара своју XIV беседу, посвећену разматрању појмова слободе и ропства. За разлику од претходне разматране X беседе, прожете киничким схватањима, XIV своју инспирацију налази у стоичкој филозофији. Уколико се у датом тексту тражи дубља анализа ропства или одређенији став самог Диона о ропству, разочарање је неминовно. Уместо тога, већи део беседе протиче у виду дијалога између Диона и неименованог лаика. Током разговора, Дион истиче нелогичности и парадоксе у прихваћеним представама о слободи и ропству. Ако је слободан онај човек који увек и искључиво делује у складу са властитом одлуком, да ли слободан човек уопште постоји? Чланове хора под надзором хоровође, болеснике који поштују савете лекара или војнике који слушају стратега нико не сматра робовима, па ипак они не могу да чине увек како би желели, већ слушају туђе наредбе, понекад крајње напорне и непријатне. ${ }^{26}$ Свакако да су велики краљеви, износи Дион највећи парадокс, попут Дарија и Ксеркса били слободни. Међутим, чак ни они нису могли да раде увек како су желели, већ су били принуђени, чак често, да се повинују туђим одлукама: Дарије се, повређен у лову, подвргао поступку који је одредио лекар, иако је овај био болан и непријатан; Ксеркс се, при повлачењу из Грчке, нашао у олуји и сасвим потчинио ауторитету капетана брода. ${ }^{27}$ Указујући на логичке недостатке у сличним ставовима о слободи и ропству, ставовима који се на први поглед чине неоспорно истинитим, Дион припрема терен за изношење старе стоичке тврдње да је само мудрац заиста слободан. ${ }^{28}$ Ма како то чудно звучало, на тај стоички концепт слободе нимало не утиче чињеница да исти мудрац може имати статус роба и носити окове. $^{29}$ У овом закључку нема ничег посебно оригиналног. Критичко разматрање ропства не налазимо ни у траговима.

Дионова XV беседа чини целину са претходном у смислу да има дијалошку форму и да, ослањајући се на врло сличну аргументацију, разматра суштину ропства и слободе. Дијалог тече између једног атинског роба и једног слободног Атињанина. Роб поставља питање да ли је заиста могуће разликовати неслободног човека од

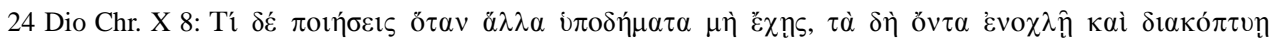

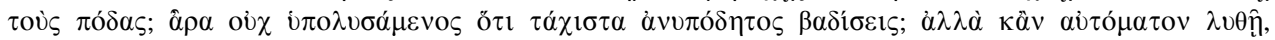

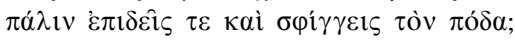

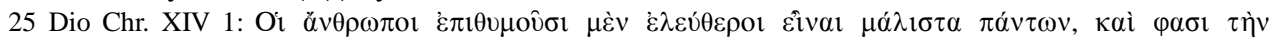

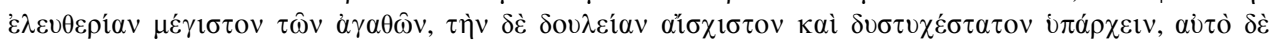

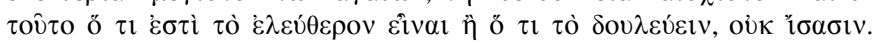

26 Dio Chr. XIV 4-7.

27 Dio Chr. XIV 8.

28 Dio Chr. XIV 18.

29 Dio Chr. XIV 19. 
слободног. Атињанин на то даје самоуверен одговор: „Уистину јесте, тако ми Зевса! Знам поуздано да сам ја слободан као и сви окупљени, али ти немаш никаквог удела у слободи.“"30 Следи опширна дебата током које роб поставља питања у погледу слободе и ропства, само да би истицао логичке слабости господаревих одговора.

И из XV беседе се јасно види да Дион сматра роба човеком. У овом случају то је чак врло одлучан и речит, дакле способан човек, који са успехом води дебату против слободног Атињанина. Међутим, ни овде, упркос снажном нападу на устаљена схватања слободе и ропстве, ми заправо не излазимо из оквира стоичке доктрине о духовној слободи и ропству. Закључак који би се односио на друштвену институцију ропства, закључак који би можда довео у питање њену моралну оправданост, тиме и њено даље постојање, изостаје. Пишући дискусије посвећене специјално појму ропства, Дион не сматра да оне имају или треба да имају одређење консеквенце на сасвим реалну и свакодневну институцију коју је виђао свуда око себе. То просто није била његова намера, она се сводила на, у овом случају, излагање једне стоичке доктрине у пригодној и допадљивој књижевној форми.

Да ли, најзад, Дион из Прусе, истакнути беседник и филозоф царске епохе, види ропство као порок, као друштвено зло? Одговор је, упркос свему, не. Дион посматра робове као људе. Он неоспорно има разумевања за робове, сиромашне грађане и друге маргиналне групе, и не одобрава њихово злостављање или безобзирно искоришћавање. То, међутим, не значи да је ослобођен социјалних предрасуда које су карактерисале његово време и средину из које је потекао. И када говори о друштвеним пороцима, неправди и искушењима људског живота, он превасходно има у виду слободне људе, понајпре грађане хеленског полиса. Дистинкције између Хелена и варвара, грађана и неграђана, слободних и робова су битне за њега, иако има више разумевања од својих савременика за људе који су остали са друге стране линије раздвајања. Ропство може бити зло или водити у друштвено зло у неким случајевима. Али ово је тек злоупотреба ропства, институције која сама по себи није за осуду нити нужно води у порок. Не може се порећи да Дион гаји извесне наде и амбиције у погледу искорењивања одређених друштвених порока. Док се за остале разматране расправе то баш не може рећи, Еубејска беседа несумњиво има елементе друштвено ангажованог дела. Њену срж чини покушај да се, кроз указивања на одређена зла, ова ублаже или искорене. Али чак и у неком бољем свету, где би пороци које Дион нарочито осуђује били искорењени (похлепа, луксуз, проституција итд.), ипак би постојали богати и сиромашни, грађани и неграђани, слободни и робови. Идеална породична заједница еубејских ловаца је похваљена јер нема робове, али оно што Дион хвали у вези са њом су скромност и самодовољност као велике врлине а не непостојање ропства као такво. За Диона, робовласништво није ни добро ни лоше, оно просто постоји, одувек и свугде. Дион из Прусе као критичар античког ропства и заговорник ослобађања робова је модерна фикција, једна од многих коју савремени свет гаји о антици.

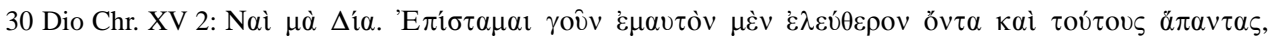

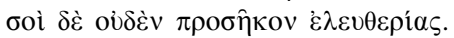




\title{
SLAVERY AS A VICE IN THE ORATORY OF DIO OF PRUSA
}

\author{
Summary
}

Slavery is, and certainly will remain to be, a grand topic for historians of both ancient and modern world. One of the more important Greek writers of imperial era, Dio of Prusa (Chrysostomos) treats this topic comparatively often: three of his discourses specifically examine what the slavery really is, while in some of the others (the famous $7^{\text {th }}$ among them) the topic features prominently. This paper examines only one of many aspects of Dio's treatment of slavery and attempts to clarify the following issue: does Dio actually condemn the institution of slavery and slave ownership and if so, are there any further, real life consequences of this view? A careful examination of the Dio's text leads to disappointing answers: no and no. It cannot be denied that Dio has a fair amount of understanding and sympathy for marginal groups of the Graeco-Roman world; if anything, the long stretch of time he spent in exile and poverty forced him to bind with such people. This understanding includes slaves as well: on several places in his speeches, Dio acknowledges that slaves are human beings and should be treated as such. His attitude on slavery, however, never goes any further then that. There are bad masters and useless slaves, but the institution of slavery as such is not good or bad, it simply exists and it is common. In the hands of a corrupted individual slavery can lead to vice, but it is not a vice by itself. While sometimes sympathizing with slaves, Dio remains to be a member of the educated and wealthy elite to whom distinctions between Greeks and barbarians, citizens and non-citizens, and free and slaves are of the highest importance. The comparatively mild attitude towards poor and slaves was not altogether unknown or strange in his day. It should be noted, however, that such attitude never translated itself into the denial of slavery or the social and political activism of any kind.

Keywords: Dio of Prusa, slaves, slavery, condemnation of slavery, second sophistics era, Roman Empire. 